\title{
Analysis of proportional conception of the historical truss Church of St. Martin in Dolní Újezd
}

\author{
Peter Krušinský ${ }^{1, *}$, Michaela Holešová $^{2}$, Eliška Racková $^{3}$ \\ ${ }^{1}$ University of Žilina, Faculty of Civil Engineering, Žilina, Univerzitna 8215/1, Slovak Republic \\ ${ }^{2}$ National heritage institute CR, Pardubice office, Zámek 5, Pardubice, Czech Republic
}

\begin{abstract}
The late-Romanesque St. Martin's Church in Dolní Újezd was probably built in the mid-13th century. The nave has a wooden joist ceiling whose beams serve as tie beams too. The Gothic vaults above the presbytery date from ' 30 s of the 15 th century. The truss of the church is dendro-dated to 1420 - 1421. Some members of a truss structure are dendro-dated to 1823 - 1824, when the repair was undertaken. The examined truss is a rafter-collar tie structure with collar beams and pedestal struts. It has a characteristic shape and may be typologically classified as a structure of the earlier period. This type of a truss structure was typically built in this region and represents one of the features occurring in the particular social and culture circles at the time.
\end{abstract}

\section{Introduction}

Analysis of proportional conception is based on historical-structural, archival and dendrochronological research of the object as a whole. The method of geometrical analysis of the concept of the roof is based of acquiring information from period literature and from previous analyses. The Proportional Relationship of historic trusses was analysed mainly from Slovakia and Czechia. The results show further comparisons. Object of research is analysing the proportion of historical structure and relation into floor plan of building and layout of the building solution. Building space solution is also built on the concept of proportional relationships. Significant part of method is determining the roof height. The roof height is proportionally and geometrically derived from the ground plan of the building. This principle has also been identified in other historical roof trusses of Slovakia and Czechia, which we were analysing (eg. roof trusses on a churches in the village of Bela Dulice, Abramova, Okolicne, Klimkovice, Vlčovice and others $[3,4,6])$.

\section{History of St. Martin's Church in Dolní Újezd}

The church was probably built in the mid-13th century. It has a late-Romanesque core dated from this century - only the tower and west nave survived to this day. In the late-14th

* Corresponding author: krusop@wp.pl 
century, a new presbytery arose on the church's eastern elevation; it is built in high-level architecture (shafts and the lower part of arch ribs survived). The old presbytery was demolished and the new one was interconnected with a late-Romanesque nave, which can be seen in the irregular floorplan. At the time of the Hussite wars, the church was destroyed by the running armies, like many other churches in this region. Soon after, today's truss, dated from 1420 - 1421d, was built. Sometimes later, probably in the '30s of the 15th century when the situation became stable, the presbytery was newly vaulted with a brick vault and stone ribs. Further modifications were made after 1533 - an addition of a northern antechapel, knocking out of windows and southern entrance. Several small modifications were made later, but they did not affect the overall appearance of the church. [1,2] (Fig. 1.)

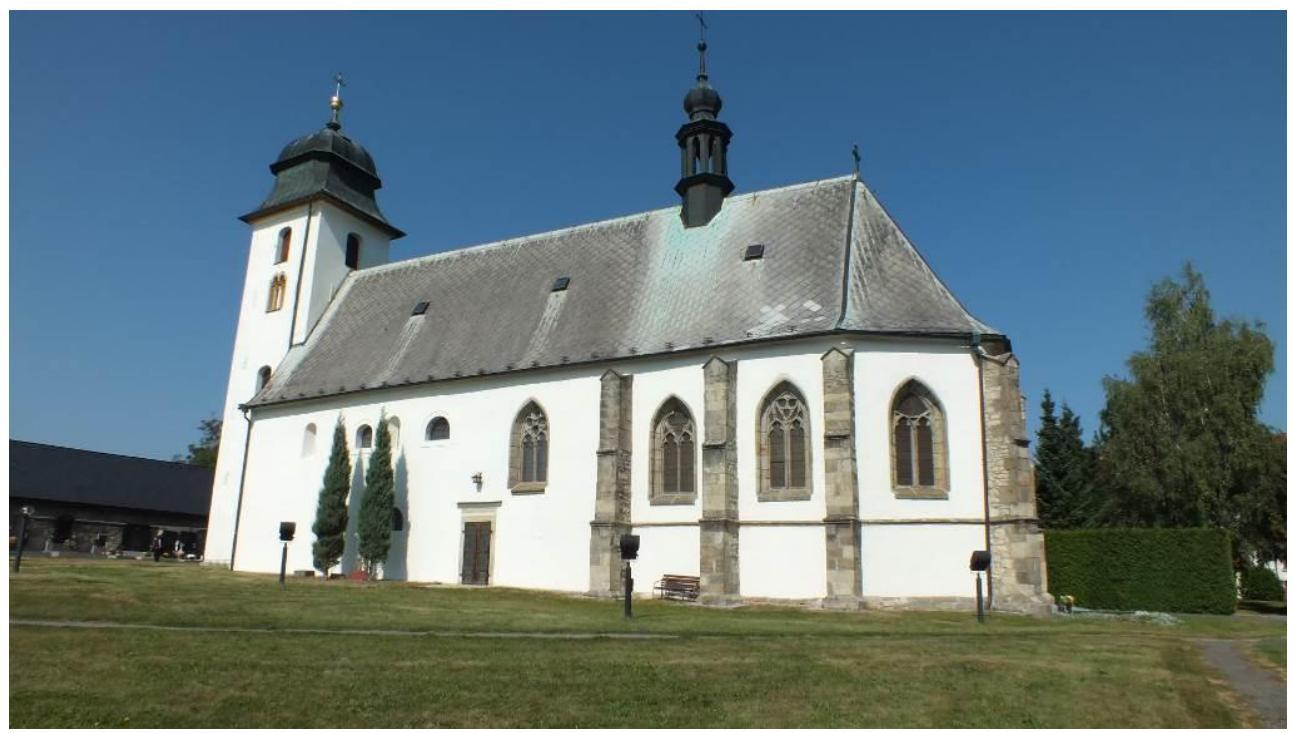

Fig. 1. The researched object - The St. Martin's Church in Dolní Újezd.

\section{Truss construction}

The church has a gable roof with a single-level ridge above the nave and sanctuary. The roof has polygonal hipped end above the polygonal end of the sanctuary. Above the sanctuary, there is a polygonal turret. The truss above the nave is a rafter-collar structure with two levels of collar beams and heel struts. The truss is longitudinally tied by a central frame that is divided into two parts by a turret. The truss as a whole contains three types of ties. The first type consists of rafters, two levels of collar beams, and a central post. The central post of the first collar beam, into which it is halved, is jointed with the second collar beam using the straight halving; the top of a post is also halved into the rafters. The post is cross-braced by the heel struts into the first level of the collar beams. The heel struts are halved into the tie beam and rafters. The collar beams are dovetailed into rafters. The second type, unlike the first one, does not contain a central post with heel struts. The crossbracing is made by a saltire cross dovetailed into the tie beam and rafters below the level of the second collar beam. The third type is similar to the second one; except to saltire crosses at the level of the first collar beam which are replaced by heel struts dovetailed into the collar beam and rafters. The truss is longitudinally braced using span pieces located on the upper and lower collar beams. The structure is longitudinally braced by saltire crosses halved and dovetailed into the posts and span pieces. (Figure 2) 

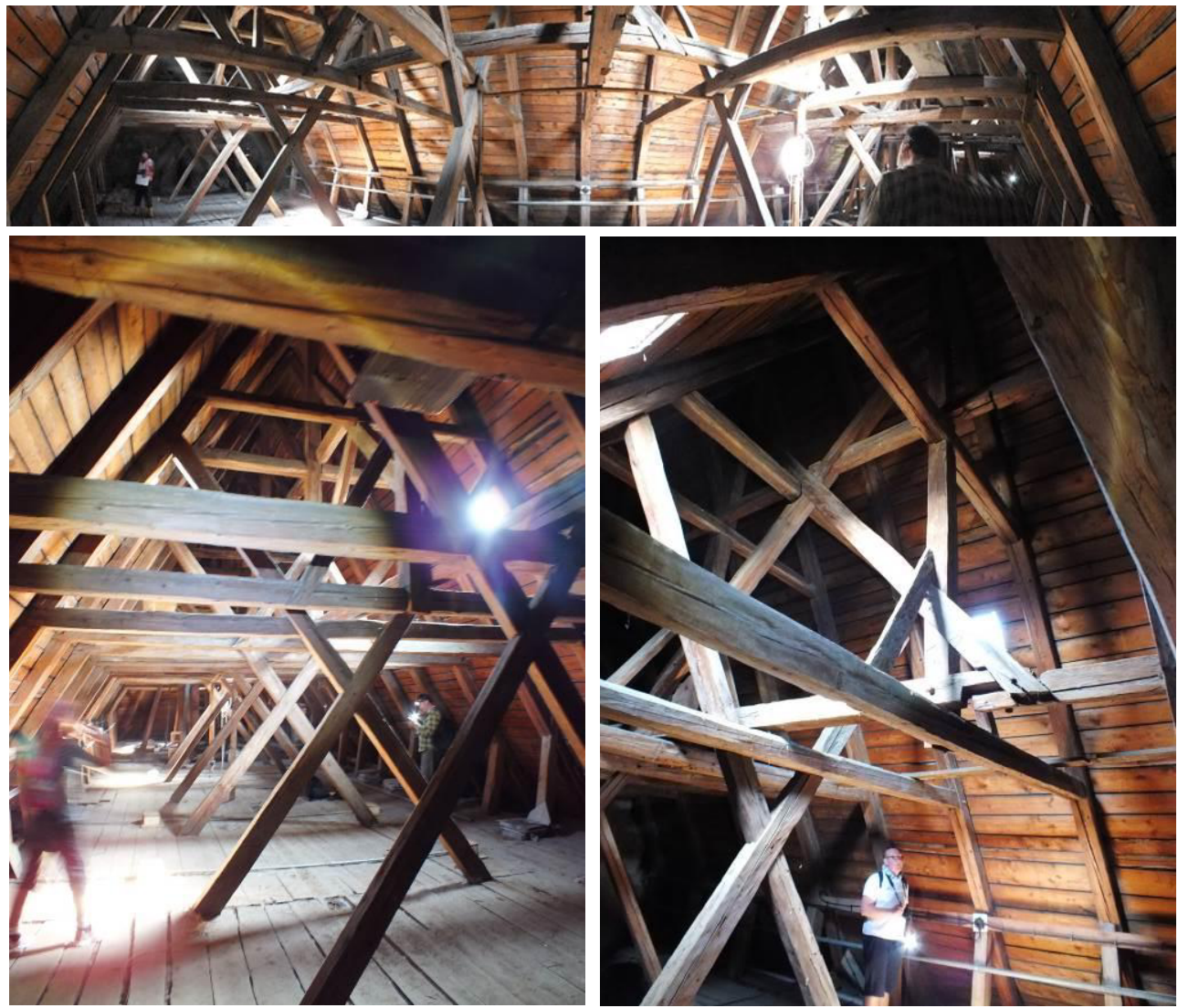

Fig. 2. The inner view of the truss

\section{Geometric concepts and proportional relationships within the truss}

Previous examination of historic trusses, mainly those of sacral buildings, suggests that one of the most commonly method used to determine the basic truss dimensions is the principle that may be named as ,n plus $\mathrm{k}$, where $\mathrm{k}=1,2,3$. The principle is used to determine the truss height on the basis of its width by the ratio method. The truss width is divided into $2 \mathrm{n}$ of $x$ units and the truss height is then $(n+k)$ of $x$ units. It is this principle where $k=3$ that was used in the St Martin's Church in the village of Dolní Újezd. The basic concept of the truss above the nave in the cross-section is derived from the basic ABCD square (Fig $\mathrm{x}$ ). $\mathrm{The} \mathrm{AB}$ side of the square stands for $\mathrm{nx}$ (within the principle $\mathrm{n}$ plus 3 ). If we divide it into $\mathrm{n}$-parts, we get the measure unit $\mathrm{x}(\mathrm{n}=4$ in this case). We can determine the truss height using the principle $(n+3) x$, on the basis of which the truss height is $7 / 4$ of the $A B$ side of the $\mathrm{ABCD}$ square. The truss width/height ratio is, using this method, 8:7. The truss above the nave contains three types of ties - A, B, and C. In all the ties (Figure 3), the position of a lower collar beam is defined as $5 / 8$ of the length of the $\mathrm{BC}$ side of the basic $\mathrm{ABCD}$ square; the position of an upper collar beam is $9 / 8$ of the $\mathrm{BC}$ side of the basic $\mathrm{ABCD}$ square. It follows that the ratio of the distance of a tie beam from a lower collar beam to the distance of both collar beams is 5:4. The heel strut is located on a tie beam at a distance of $\mathrm{x}$ from the position of a rafter heel (i.e. 1/8 of the truss width) and positioned on a rafter in a height 
of $3 / 8$ of the length of the $\mathrm{BC}$ side of the ABCD square (Figure 4). The joints of a heel strut of a post in the A-tie are located on a post at a distance of 11/12 of a length of the BC side of the $\mathrm{ABCD}$ square from the tie beam end. The heel struts of a post are horizontally positioned on a lower collar beam at a distance of $1 / 6$ of a length of the $A B$ side.

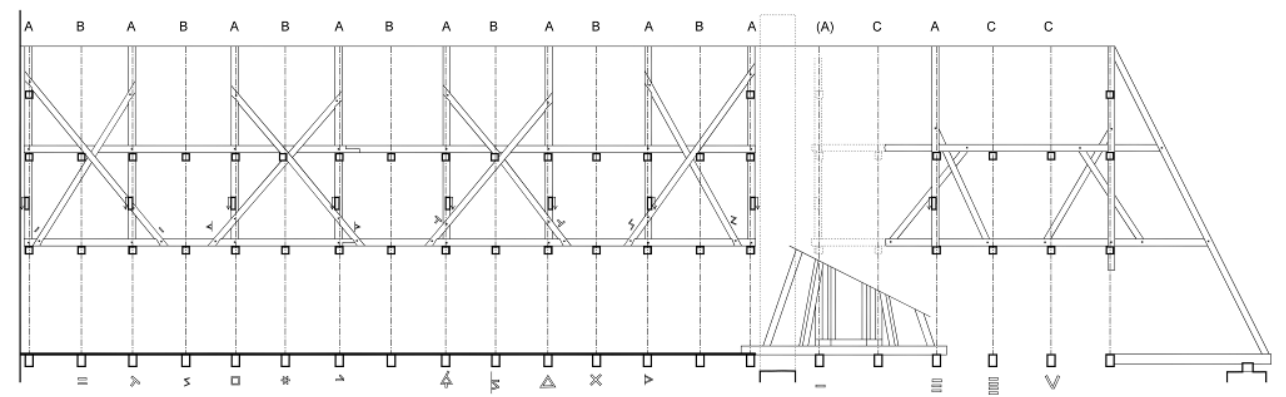

Fig. 3. Longitudal truss section.

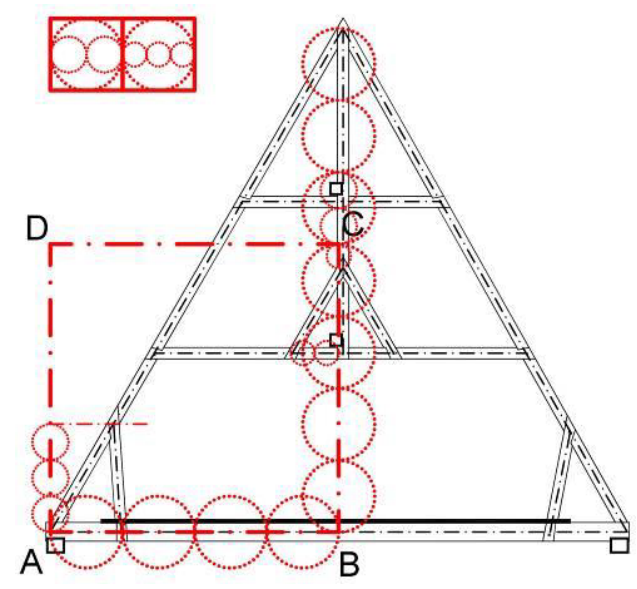

Fig. 4. Longitudal section of the truss.

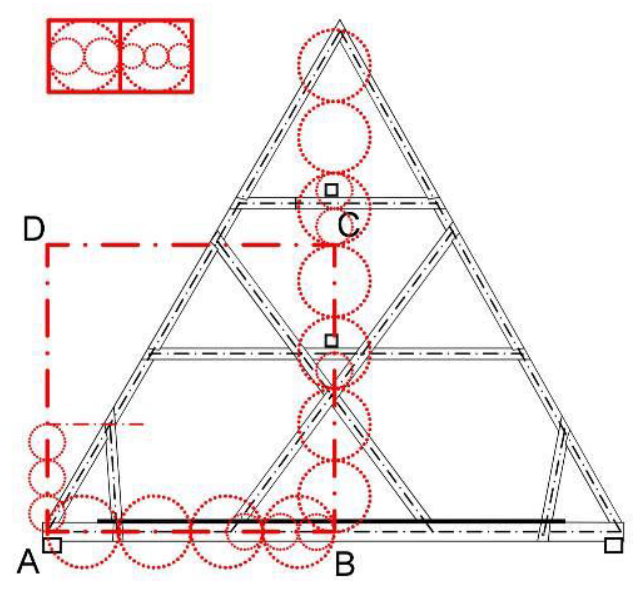

Fig. 5. B cross-section of the truss.

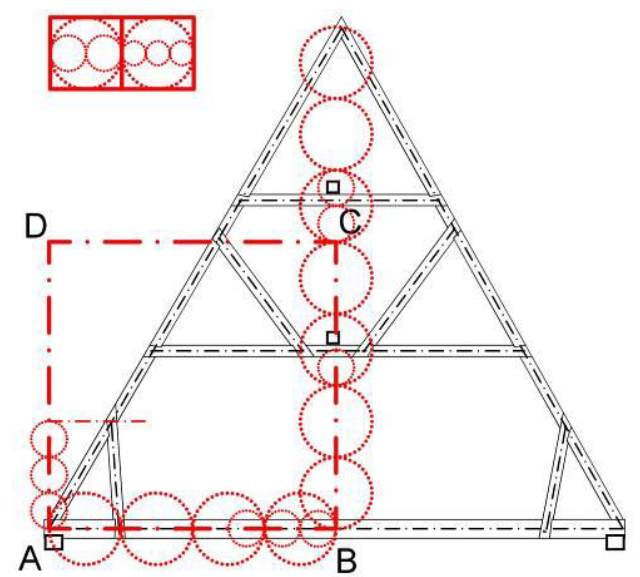

Fig. 6. $C$ cross-section of the truss. 
The transversal B-tie is braced by a saltire cross. The strut joint is located on a tie beam at a distance of $5 / 8$ of the $\mathrm{AB}$ side of the $\mathrm{ABCD}$ square from a rafter heel. The rafter heel joint is determined by the basic $\mathrm{ABCD}$ square. (Figure 5) The transversal $\mathrm{C}$-tie of a truss is derived from the B-tie; the heel struts at a level of a lower collar beam respect the slope and position of the struts in a saltire cross of the B-tie (Figure 6).

\section{Conclusion}

The method of a ratio conception to design a truss in relation to the floorplan is visible and identified in the examined building. The foundation is to use a period system to determine the height and position of individual truss members, as known from later literature. The ratio analysis of a truss structure and building itself may help study its historic development. [7] Identification of historic measures (on the basis of a division), ratios, and construction used may reveal how the cultural circles and socio-economic ties influenced regional architecture. Information on proportional and geometric conception may be a guideline for a recovery methodology in relation to the conservation of historic buildings. $[8,9]$ The similar analysis of the truss and its proportional relations in the All Saints Church in Vlčovice in Silesia revealed the similar method "n plus 2" was used to determine the truss height (Figure 7), in the rural house in Vápenná [4,5] as well as in the Trinity Church in Klimkovice (also situated in Silesia) is the use of the similar principle to determine a truss height - the principle of "n plus one". The main difference is in the number of $x$ units within a side of the basic square defining the truss structure. Individual divisions of the basic square refer to the potential use of a linear measure system, which should be subjected to further detailed examination. To understand time and spatial relationships better, it is necessary to carry out more analyses focused on the truss designing and conceptions in order to create an extensive statistical database for numerical analyses.

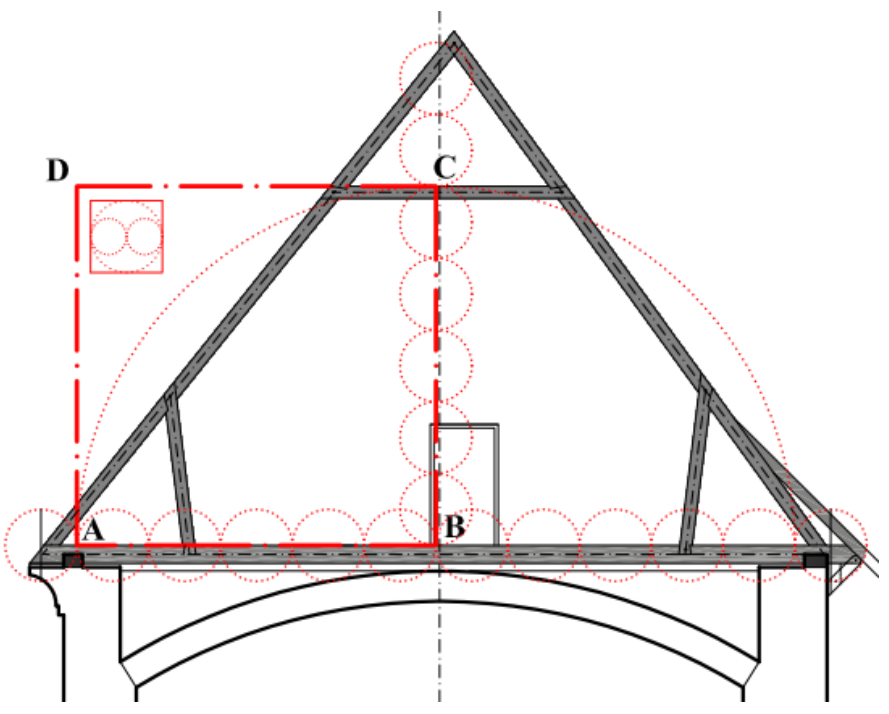

Fig. 7. Cross-section of the truss The All Saints Church in Vlčovice. 


\section{References}

1. D. Líbal: Katalog gotické architektury v České republice do husitských válek. 1. vyd. Praha: Unicornis (2001)

2. F. Václavík, Nové poznatky ze stavební historie kostela sv. Martina v Dolním Újezdě okr. Svitavy, in: Výroční zpráva za rok 2000. V Pardubicích: Památkový ústav v Pardubicích, 201-203 (2000)

3. P. Krušinský, E. Capková, J. Gocál, Advanced Materials Research. 1122, 243-248 (2015)

4. P. Krušinský, E. Capková, J. Gocál, M. Holešová, Civil and environmental engineering: Scientific technical journal 11/2, 136-141 (2015)

5. P. Krušinský, E. Capková, L. Augustinková, R. Korenková, Civil and Environmental Engineering. 12/2, 111-115 (2016)

6. J. Gocál, P. Krušinský, E. Capková, M. Kekeliak, Advanced materials research. 969, 199-207 (2014)

7. A. Struhár, "Geometric harmony of historical architecture in Slovakia." Bratislava. Pallas, (1977)

8. O. Makýš, "Včasnohistorické a rannostredoveké drevené a drevozemné pamiatky : hypotetické rekonštrukcie a konzervácia." 1. vyd. Pezinok : Renesans (2014)

9. A. Iringová, R. Idunk, Civil and environmental engineering: Scientific technical journal. 12/2, 84-93 (2016) 